\title{
Anatomo-pathological aspects of parasitism by nematodes of the superfamily Metastrongyloidea in wild crab-eating fox (Cerdocyon thous) in Midwestern Brazil
}

\author{
Jair Alves Ferreira Júnior ${ }^{*}$ Guilherme Reis Blume ${ }^{2}$ Susy Karoline Hermes de Sousa ${ }^{1}$ \\ Clarissa Machado de Carvalho ${ }^{3}$ Chris Gardiner $^{4}$
}

\footnotetext{
${ }^{1}$ Laboratório de Patologia Veterinária, Universidade de Brasília (UnB), 70910-900, Brasília, DF, Brasil. Email: jairalvesfjunior@gmail.com. "Corresponding author.

${ }^{2}$ Laboratório de Diagnóstico Patológico Veterinário, Universidade de Brasília (UnB), Brasília, DF, Brasil.

${ }^{3}$ Consultório Mundo Silvestre, Asa Norte, Brasília, DF, Brasil.

${ }^{4}$ Veterinary Pathology Service, Joint Pathology Center, Silver Spring, MD, USA.
}

\begin{abstract}
Nematodes of the superfamily Metastrongyloidea affect the respiratory, cardiovascular, and nervous systems of domestic carnivores and are uncommonly detected in wild animals. This report describes the lesions associated with pulmonary parasitism by nematodes of the superfamily Metastrongyloidea in a wild crab-eating fox (Cerdocyon thous) in the Federal District, Brazil. Grossly, there was pulmonary hyperemia, edema, and emphysema. Microscopically, there was granulomatous arteritis associated with intravascular metastrongylid. The anatomical location, characteristic lesion, and histological features of the parasite suggested that the nematode involved in this case is Angiostrongylus vasorum. This worm is frequently reported parasitizing pulmonary arteries of domestic canids but is uncommonly described in wild canids in Midwestern Brazil.

Key words: Angiostrongylus, nematode, wild canids, pathology.
\end{abstract}

Aspectos anatomopatológicos do parasitismo por nematódeos da superfamília Metastrongyloidea em cachorro-do-mato (Cerdocyon thous) de vida livre no Centro-Oeste brasileiro

RESUMO: Nematódeos da superfamília Metastrongyloidea afetam o sistema respiratório, cardiovascular e nervoso de carnívoros domésticos e são incomuns em animais silvestres. Este trabalho descreve os achados anatomopatológicos de um caso de parasitismo pulmonar por nematódeos da superfamília Metastrongyloidea em um cachorro-do-mato (Cerdocyon thous) de vida livre no Distrito Federal. Macroscopicamente, o pulmão apresentou hiperemia, edema e enfisema e, no exame histológico, notou-se arterite granulomatosa associada à metastrongilídeos intravasculares. A localização anatômica, o tipo de lesão observada e os aspectos histológicos do parasito sugerem que o nematódeo, envolvido neste caso, seja o Angiostrongylus vasorum, que é frequentemente descrito parasitando artérias pulmonares de canídeos domésticos, porém, é incomumente descrito em canídeos silvestres, principalmente no Centro-Oeste brasileiro.

Palavras-chave: Angiostrongylus, nematódeo, canídeos silvestres, descrição anatomopatológica.

The crab-eating fox (Cerdocyon thous) is a canid widely distributed in South America. In Brazil, with the exception of the Amazon Basin, this species is widely distributed, especially in the Midwestern region. This canid is omnivorous and eat carcasses of small mammals (COURTENAY \& MAFFEI, 2004).

The superfamily Metastrongyloidea is composed of nematodes that infect the respiratory, cardiovascular, and nervous systems of mammals. This superfamily includes the Angiostrongylidae family, which contains the genus Angiostrongylus, with nematodes found mostly in the pulmonary artery, its ramifications, and the right ventricle of carnivores (BOWMAN, 2010; SPRATT, 2015). A parasitological review of wild carnivores in Brazil revealed Angiostrongylus in crab-eating fox (C. thous) (VIEIRA et al., 2008); however, the information about the morphological changes caused by these parasites is scarce. Other authors reported lesions associated with this parasitism in a coyote (Canis latrans) in Canada (BOURQUE et al., 2005). Our report described the histopathological findings associated with the parasitism by nematodes of the superfamily Metastrongyloidea in a wild crab-eating fox (C. thous) in the Federal District, Midwestern Brazil.

A free-ranging adult, female crab-eating fox (C. thous) was admitted by the government wildlife screening center (Centro de Triagem de Animais Silvestres) to the teaching veterinary hospital of Universidade de Brasília with a history of multiple 
fractures. Radiographical examination revealed a complete vertebral fracture in the eighth thoracic vertebra (T8). Additionally, the urine was dark red. This animal was euthanized with intramuscular ketamine, xylazine, and intracardiac potassium chloride due to poor prognosis. At necropsy, samples of multiple organs were collected and subsequently fixed in $10 \%$ buffered formalin. Tissues were processed for routine histopathological evaluation and stained with hematoxylin and eosin.

Grossly, mild hemoperitoneum and hemothorax were noted. There was a focal discrete fibrinous adhesion of the omentum to the parietal peritoneum, and moderate focally extensive hemorrhage in the adjacent muscles, capsule, and hilum of the right kidney. Lungs were not collapsed and presented areas of focally extensive emphysema in the cranial lobes and severe congestion in the caudal lobes (Figure 1A). There was mild edema in the tracheal and bronchial lumen. The mucosa of the duodenum and jejunum presented moderate hyperemia. The urine was mildly brownish. There was a simple and complete fracture in the ventral region of the body of T8. Muscles and adjacent pleura were intensely hemorrhagic.

Microscopically, four transversal sections of the nematodes of the superfamily Metastrongyloidea, measuring about 200-300 $\mu \mathrm{m}$ in diameter, were observed in the lumen of the pulmonary artery (Figure 1B). Nematodes had a pseudocoelom with smooth eosinophilic cuticle, coelomyarian-polymyarian musculature, accessory hypodermal chords, small lateral chords, an intestine with few multinucleated cells (Figure 1D), and a developed reproductive system. Reproductive tract was composed of a large uterus containing a moderate amount of irregular structures, consistent with developing eosinophilic eggs. In the wall of the artery, there was moderate multifocal to coalescing infiltration of macrophages, epithelioid cells, few lymphocytes, eosinophils, and multinucleated giant cells expanding to the subendothelial layer (Figure 1C). These findings are consistent with moderate multifocal to coalescing granulomatous arteritis. There were multifocal areas of moderate atelectasis, moderate edema, and congestion.

InBrazil,thereareparasitologicaldescriptions of Angiostrongylus spp. in wild animals, such as the jaguarundi (Puma (Herpailurus) yagouaroundi) (VIEIRA et al., 2013), hoary fox (Dusicyon vetulus) (LIMA et al. 1994), montane grass mouse (Akodon montensis) (SOUZA et al., 2009), and crab-eating fox (C. thous) (TRAVASSOS 1927; TRAVASSOS \& FREITAS 1943; VICENTE et al., 1997; DUARTE et al., 2007). Cases of parasitism by Angiostrongylus spp. in $\boldsymbol{C}$. thous were reported in the states of Rio de Janeiro and Mato Grosso do Sul (TRAVASSOS \& FREITAS 1943); whereas, A. raillieti was described in Rio de Janeiro (TRAVASSOS, 1927) and Goiás (VICENTE et al., 1997), and $\boldsymbol{A}$. vasorum in Minas Gerais (DUARTE et al., 2007). However, detailed pathological studies of this infection in wild animals are extremely scarce.

In the current report, the cause of death was multiple traumas, probably due to a car accident. Although significant parasitic vascular changes in the lung were observed, this finding was considered incidental. Morphologically these parasites are compatible with nematodes of the superfamily Metastrongyloidea, most probably Angiostrongylus. Features such as the coelomyarian-polymyarian musculature, accessory hypodermal chords, intestine with few multinucleated cells, developed the reproductive system, and location of these parasites support this hypothesis since these characteristics are widely described for metastrongylids (GARDINER \& POYNTON, 2006). Final confirmation of this nematode could be made with parasitological or molecular tests, such as polymerase chain reaction (PCR). Gross lesions characterized by poorly defined, scattered, slightly firm nodules in the lungs were reported in a coyote (Canis latrans) parasitized by A. vasorum in Canada (BOURQUE et al., 2005). In the present case, gross pulmonary lesions related to parasites were not seen. Vascular lesions caused by adult Angyostrongylus spp. occur mainly in the lung and consist of lymphoplasmacytic, eosinophilic, or granulomatous inflammation with hypertrophy of the tunica intima and media (proliferative arteritis) and thrombosis (BOURQUE et al., 2005). In some cases, it may also present as granulomatous and eosinophilic pneumonia due to embolism of eggs and larvae (CASWELL \& WILLIAMS, 2015). Histological findings of the current case are similar to those described previously in other canids affected by this parasite; however, there was no extravasation of eggs and larvae into the interstitial space. The main differential diagnosis for A. vasorum in canids is Dirofilaria immitis, which also parasitizes the pulmonary arteries. Eucoleus aerophilus, Crenosoma vulpis, Filaroides hirthi and Andersonstrongylus milksi can also affect lungs of domestic and wild canids. However, these parasites only parasitize the pulmonary airways and alveoli (CASWELL \& WILLIAMS, 2015).

Based on the histopathological findings, the diagnosis of moderate multifocal to coalescing granulomatous arteritis associated with intralesional nematodes of the superfamily Metastrongyloidea 


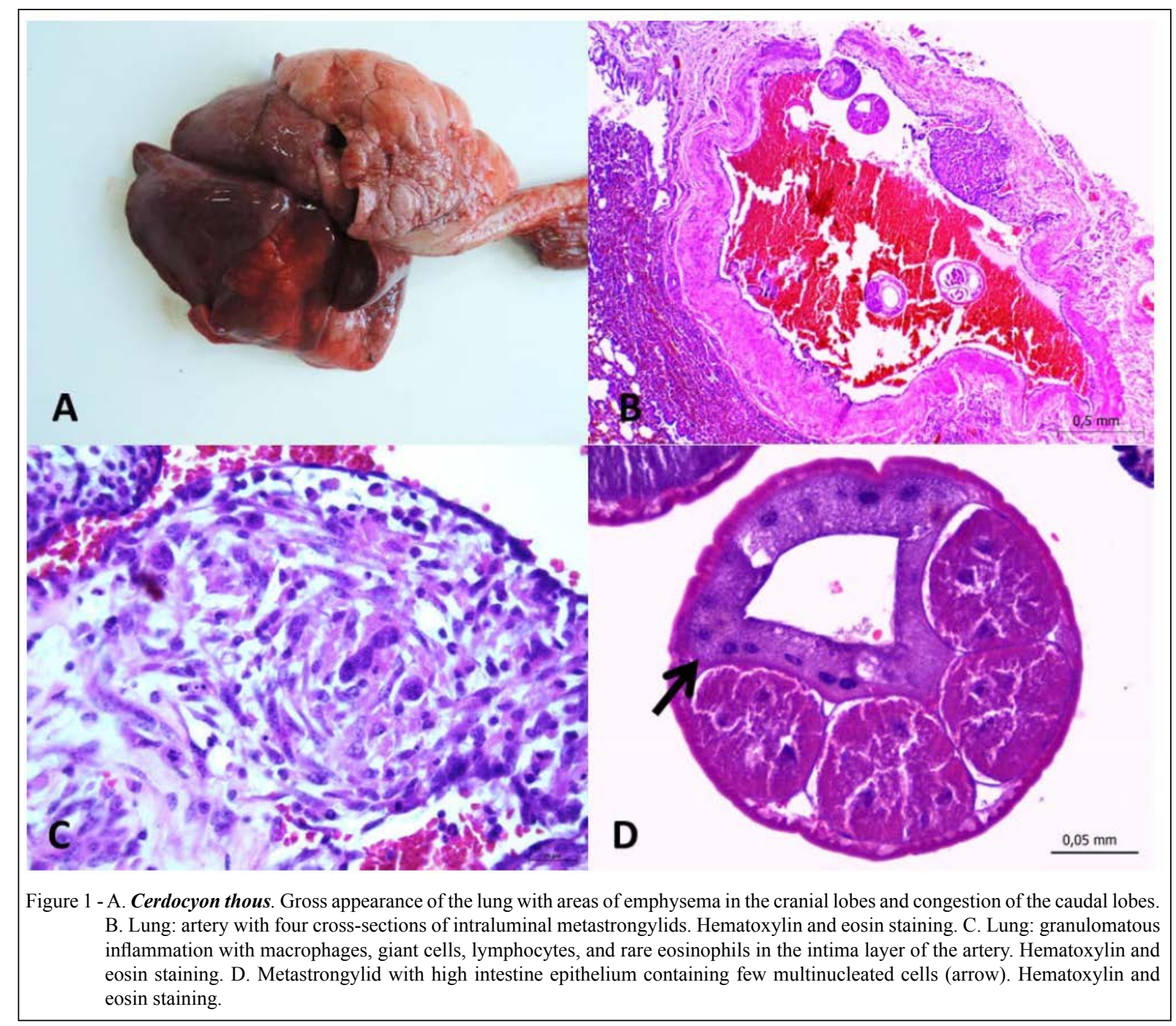

was diagnosed in a wild crab-eating fox (C. thous). Anatomical location, lesion, and histological aspects of the parasite suggest that the nematode involved in this case is $\boldsymbol{A}$. vasorum, frequently described as parasitizing the pulmonary arteries of domestic canids, but it is uncommon in wild canids. This is the first report of this disease in wild canids in the Federal District, Midwestern Brazil.

\section{REFERENCES}

BOURQUE, A. et al. Angiostrongylus vasorum infection in coyote (Canis latrans) from Newfoundlandand Labrador, Canada. Journal of Wildlife Disease, v.41, p.816-819, 2005. Available from: <http:/ www.bioone.org/doi/full/10.7589/0090-3558-41.4.816>. Accessed: out 04,2015 . doi: 10.7589/0090-3558-41.4.816.

BOWMAN, D.D. Helmintos. In: GEORGIS. Parasitologia veterinária. 9. ed. Rio de Janeiro: Elsevier, 2010. p. 175-179.
CASWELL, J. L.; WILLIAMS, K. J. Respiratory system. In: MAXIE, M.G. Jubb, Kennedy, and Palmer's pathology of domestic animals, 6. ed. St. Louis, Missouri: Saunders Elsevier, 2015. V.2, Cap. 5, p. 465-591.

COURTENAY, O.; MAFFEI, L. Crab eating fox, Cerdocyon thous (Linnaeus, 1766). In: SILLERO-ZUBIRI, C. et al. Canids: foxes, wolves, jackals and dogs. Status survey and conservation action plan. Cambridge, UK: IUCN/SSC Canid Specialist Group, 2004. p. 30-38.

DUARTE, F. H. et al. Occurrence Angiostrongylus vasorum (Raillet, 1866) (Nematoda, Angiostrongylidae) in Cerdocyon thous Linnaeus, 1766 (Carnivora, Canidae) in Minas Gerais State, Brazil. Arquivo Brasileiro de Medicina Veterinária e Zootecnia, v. 59, p. 1086-1088, 2007. Available from: <http:// dx.doi.org/10.1590/S0102-09352007000400042>. Accessed: out 08, 2015. doi: 10.1590/S0102-09352007000400042.

GARDINER, C. H.; POYNTON, S.L. An atlas of metazoan parasites in animal tissues. Washington, D. C.: Armed Forces Institute of Pathology, 2006. 64p. 
LIMA, W. S. et al. Occurrence of Angiostrongylus vasorum in the lungs of the Brazilian fox Dusicyon vetulus. Journal of Helminthology, v.68, p.87, 1994. Available from: <http://dx.doi. org/10.1017/S0022149X00013547>. Accessed: out 14, 2015. doi: $10.1017 / \mathrm{S} 0022149 \mathrm{X} 00013547$.

SOUZA, J. G. R. et al. A new metastrongylid species (Nematoda: Metastrongylidae): a lungworm from Akodon montensis (Rodentia: Sigmodontinae) in Brazil. Journal of Parasitology, v.95, p.15071511, 2009. Available from: <http://dx.doi.org/10.1645/GE-2013.1>. Accessed: out 14, 2015. doi: 10.1645/GE-2013.1.

SPRATT, D. M. Species of Angiostrongylus (Nematoda: Metastrongyloidea) in wildlife: a review. International Journal for Parasitology: Parasites and Wildlife, v.4, p.178-189, 2015. Available from: $<$ http://dx.doi.org/10.1016/j.ijppaw.2015.02.006>. Accessed: out 08, 2015. doi: 10.1016/j.ijppaw.2015.02.006.

TRAVASSOS, L. Novos nematódeos. Boletim Biológico, v.6, p.52-61, 1927.
TRAVASSOS, L.; FREITAS, J. F. T. Relatório da sétima excursão científica do Instituto Oswaldo Cruz, realizada a zona da Estrada de Ferro Noroeste do Brasil, em maio de 1942. Memórias do Instituto Oswaldo Cruz, v.38, p.385-412, 1943.

VICENTE, J. J. et al. Nematóides do Brasil. Parte V: Nematóides de mamíferos. Revista Brasileira de Zoologia, v.14, p.1452, 1997. Available from: <http://dx.doi.org/10.1590/S0101-81751997000500001>. Accessed: out 14, 2015. doi: 10.1590/S0101-81751997000500001.

VIEIRA, F. M. et al. Checklist of helminth parasites in wild carnivore mammals from Brazil. Zootaxa, v.1721, p.1-23, 2008. Available from: $<$ http://www.ufrrj.br/laboratorio/parasitologia/arquivos/publicacao/3_ LIVRO.pdf $>$. Accessed: out 08, 2015. doi: 10.15468/jvxypi.

VIEIRA, F. M. et al. A new metastrongyloidean species (Nematoda) parasitizing pulmonary arteries of Puma (Herpailurus) yagouaroundi (É. Geoffroy, 1803) (Carnivora: Felidae) from Brazil. Journal of Parasitology, v.99, p.327-331, 2013. Available from: <http://dx.doi.org/10.1645/GE3171.1>. Accessed: out 04, 2015. doi: 10.1645/GE-3171.1. 